\title{
EFFECT OF MESENCHYMAL STEM CELL - DERIVED EXTRACELLULAR VESICLES ON ACETAMINOPHEN - INDUCED NEPHROTOXICITY IN ADULT MALE ALBINO RATS
}

\author{
By
}

\section{Saad Mohammad Mohammad, Osama Mohammad Mohammad Abd El- Hay, Ibrahim Hassan Mohammad* and Ahmad Mansour Yosuf Kandil**}

\author{
Medical Physiology, Biochemistry* and Pathology** Departments, Al-Azhar Faculty of \\ Medicine.
}

\begin{abstract}
Background: Novel therapies are urgently needed to address the rising incidence and prevalence of acute kidney injury (AKI) and chronic kidney disease (CKD). Mesenchymal stem cells (MSCs) can generate extracellular micro vesicles (EVs) with intrinsic protective or regenerative capacity.

Objectives: Studying the possible role of EVs generated from bone marrow-derived mesenchymal stem cells (BM MSCs) in regeneration of kidney tissue in acetaminophen-induced renal failure (RF).

Patients and Methods: Twenty four adult male albino rats of a local strain were chosen as an animal model for this study. They were divided into 4 equal groups: control, RF, RF received culture media, and RF received MSCs-derived EVs. Renal failure (RF) was induced by oral administration of acetaminophen. At the end of the experiment (24 days), blood samples were obtained for serum creatinine, urea, malodialdehyde (MDA) and tumor necrosis factor alpha (TNF- $\alpha$ ). Animals were sacrificed, and kidney tissue was obtained for histopathological examination and immunohistochemical examination for BAX protein expression, in addition to BCL2 gene expression by real time (RT) PCR.
\end{abstract}

Results: There was a significant decrease in BCL2 gene expression in addition to significant increases in serum creatinine, urea, MDA and TNF- $\alpha$ in acetaminophen- treated group. There was an increased BAX protein expression by immunohistochemistry in acetaminophen- treated group. There were significant increase in BCL2 gene expression, and significant decreases in serum creatinine, urea, MDA and TNF- $\alpha$ in MSCs-derived EVs - treated group. There was a decrease in BAX protein expression by immunohistochemistry in MSCs derived EVs - treated group.

Conclusion: BM MSCs-derived (EVs) have a role in regeneration of kidney tissue in acetaminopheninduced renal failure through antioxidant, anti-inflammatory and anti-apoptotic mechanisms.

Key words: BM MSCs-derived EVs, apoptosis and acetaminophen.

\section{INTRODUCTION}

Kidney disease is a prominent challenge for health care systems. Incidence and mortality rates of both acute kidney injury (AKI) and chronic kidney disease (CKD) have increased in recent decades (Lozano et al., 2012). CKD, a condition characterized by a gradual loss of kidney function, is estimated to be quite prevalent (Hsu and Powe, 2017). The final 
stage of CKD, when there is an irreversible loss of renal function, will mandate dialysis or kidney transplantation (Onuigbo, 2013). CKD may progress to end-stage renal disease (ESRD), resulting from a maladaptive response to injury, with fibrosis and progressive loss of function (Campion et al., 2017). ESRD can result from a variety of factors including genetic (e.g. congenital dysplasia or aplasia, reflux, polycystic kidney disease, Alport syndrome, Finnish nephropathy etc.), and environmental (IgA nephropathy, Type II diabetes, toxic or viral insult). The etiology influences the potential strategy for maintenance and/or replacement of renal function (Onuigbo, 2013).

Mesenchymal stem cells (MSCs) are multipotent cells with self-renewal, regenerative, proliferative, and multilineage differentiation potential (Charbord, 2010). By definition, MSCs are characterized by the expression of MSC markers and the ability to differentiate into adipocytes, chondrocytes, and osteocytes (Kwon et al., 2016). Emerging evidence supports the existence of kidney-resident MSCs, which originate from renal pericytes that form an extensive network around the microvasculature (Bruno et al., 2014).

In the last decades, many reports demonstrated the improvement of renal dysfunction by the administration of stem cells (Roushandeh et al., 2017). In particular, mesenchymal stromal cells (MSCs) have been extensively used in experimental models of kidney injury as well as in clinical trials (Tetta et al., 2016). The described mechanism of action is mainly due to the release of trophic factors including growth factors, cytokines and extracellular vesicles (EVs), favoring tissue repair and reducing inflammation (Cantaluppi et al., 2013). Literature data highlight the use of stem cell-derived EVs as innovative option, alternative to cell based strategies, to treat renal failure in pre-clinical models (Bruno and Camussi, 2014).

This work focused on the possible curative role of MSCs-derived EVs in acetaminophen- induced hepatorenal failure.

\section{MATERIAL AND METHODS}

Twenty four adult male albino rats of a local strain were chosen as on animal model for this study. They were kept in suitable cages $(20 \times 32 \times 20 \mathrm{~cm}$ for every three rats) at room temperature, with the natural light / dark cycle. They weighed $120-140 \mathrm{~g}$ (average weight was $130 \mathrm{~g}$ ). They were fed on a standard food in addition to green vegetables with free water supply. They were kept for 10 days for the adaptation to the new environments before the start of the experiment. The animals were divided into four equal groups:

Group I (control) received distilled water $1 \mathrm{ml} / \mathrm{rat}$ by oral gavage for three days. Group II (renal failure): RF was induced by oral administration of acetaminophen $(500 \mathrm{mg} / \mathrm{kg})$ for three days (Gopi et al., 2010). Group III (RF + vehicle): Rats received culture media (Dulbecco's modified Eagle's medium DMEM), by single intravenous injection in the caudal vein of $1 \mathrm{ml} /$ rat in the fourth day after induction of RF. Group IV (RF + BM MSCs-derived EVs): Rats received $\mathrm{BM}$ MSCs-derived $\mathrm{EVs}$ by 
intravenous injection in the caudal vein, one million cells per rat in the fourth day after induction of RF. After twenty days from BM MSCs injection, blood samples were taken from the retro-orbital vein for measurement of serum creatinine (Folin and $W u, 1976)$, urea (Patton and Crouch, 1977), TNF- $\alpha$ (Petrovas et al., 1999) and MDA (Placer et al., 1966).

Mesenchymal stromal cells were expanded until $80 \%$ of confluence with DMEM low glucose (10\% FBS). At high density confluence, culture growth medium was changed to serum-free DMEM low glucose. After $48 \mathrm{~h}$, the conditioned medium was collected and centrifuged at $2,000 \mathrm{~g}$ for $30 \mathrm{~min}$ at $4^{\circ} \mathrm{C}$ to remove cells and cellular debris. The conditioned medium was subjected to ultracentrifugation at $100,000 \mathrm{~g}$ for $2 \mathrm{~h}$ at $4^{\circ} \mathrm{C}$, using a SW28 rotor (Optima L-90K, Beckman Coulter, USA). Finally, the pellet containing MVs-MSCs was resuspended in PBS and stored at $-80^{\circ} \mathrm{C}$ (Théry et al., 2006).

Kidneys were excised for histopathological studies and immunohistochemical studies. The specimens were preserved in $10 \%$ formalin solution. Paraffin blocks were then made for the tissue samples, and different sections were obtained and stained with hematoxyline and eosin $(\mathrm{Hx}$ and E), and examined using a light microscope (Banchroft et al., 1996). Other slides were kept without staining for BAX protein detection by immunohistochemistry (Krajewski et al., 1995). Detection of BCL2 gene expression in the kidney tissue was done by real time-polymerase chain reaction (RT-PCR) (Pfaffl, 2001).

Results were analyzed using statistical program of social sciences (SPSS) for windows (version 17, SPSS Inc., Chicago, IL, USA). Values of the measured parameters were expressed as mean value \pm standard deviation (SD), differences and significances were verified by one-way ANOVA followed by the Fisher's least significant difference (LSD) post hoc test. $P$ values less than 0.05 were considered statistically significant. 


\section{RESULTS}

Effects of MSCs-derived extracellular vesicles (Table1):

In group $\mathrm{I}$, the mean \pm standard deviation of BCL2 gene expression and serum creatinine, urea, MDA and TNF- $\alpha$ were $1.25 \pm 0.069, \quad 1.07 \pm 0.15 \mathrm{mg} / \mathrm{dl}$, $27.14 \pm 3.23 \mathrm{mg} / \mathrm{dl}, \quad 19.73 \pm 1.37 \mu \mathrm{mol} / \mathrm{L} \&$ $28.29 \pm 2.84 \mathrm{Pg} / \mathrm{ml}$ respectively. In Group II, the mean \pm standard deviation of BCL2 gene expression and serum creatinine, urea, MDA and TNF- $\alpha$ were $0.37 \pm 0.097$, $8.71 \pm 1.01 \mathrm{mg} / \mathrm{dl}, \quad 71.99 \pm 3.41 \mathrm{mg} / \mathrm{dl}$, $45.41 \pm 3.85 \mu \mathrm{mol} / \mathrm{L} \& 91.6 \pm 3.29 \mathrm{Pg} / \mathrm{ml}$ respectively. There were significant decrease in BCL2 gene expression and significant increases in serum creatinine, urea, MDA and TNF- $\alpha$ in group II when compared to group I.
In group III, the mean \pm standard deviation of BCL2 gene expression and serum creatinine, urea, MDA and TNF- $\alpha$ were $0.42 \pm 0.036, \quad 9.53 \pm 1.92 \mathrm{mg} / \mathrm{dl}$, $76.12 \pm 4.06 \mathrm{mg} / \mathrm{dl}, 46.67 \pm 4.91 \mu \mathrm{mol} / \mathrm{L} \&$ $85.69 \pm 6.32 \mathrm{Pg} / \mathrm{ml}$ respectively. There were no significant differences in group III when compared to group II.

In group IV, the mean \pm standard deviation of BCL2 gene expression and serum creatinine, urea, MDA and TNF- $\alpha$ were $1.02 \pm 0.019, \quad 5.77 \pm 2.06 \mathrm{mg} / \mathrm{dl}$, $44.21 \pm 4,15 \mathrm{mg} / \mathrm{dl}, 30.47 \pm 1.25 \mu \mathrm{mol} / \mathrm{L} \&$ 47.24 $\pm 5.97 \mathrm{Pg} / \mathrm{ml}$ respectively. There were significant increase in BCL2 gene expression and significant decreases in serum creatinine, urea, MDA and TNF- $\alpha$ in group IV when compared to group II.

Table (1): Changes in BCL2 gene expression in the kidney tissue by RT-PCR and serum creatinine, urea, MDA and TNF- $\alpha$ (mean \pm standard deviation)

\begin{tabular}{|c|c|c|c|c|}
\hline Parameters & Group (I) & Group (II) & Group (III) & Group (IV) \\
\hline BCL2 & $1.25 \pm 0.069$ & $\begin{array}{c}0.37 \pm 0.097 \\
\mathrm{P}<0.0001 * \mathrm{a}\end{array}$ & $\begin{array}{c}0.42 \pm .036 \\
P>0.05 b\end{array}$ & $\begin{array}{l}1.02 \pm 0.019 \\
\mathrm{P}<0.0001 * \mathrm{c}\end{array}$ \\
\hline Creatinine (mg/dl) & $\mathbf{1 . 0 7} \pm 0.15$ & $\begin{array}{c}\mathbf{8 . 7 1} \pm \mathbf{1 . 0 1} \\
\mathrm{P}<0.0001 * a\end{array}$ & $\begin{array}{c}9.35 \pm 1 . .92 \\
P>0.05 b\end{array}$ & $\begin{array}{l}4 . .77 \pm . \cdot 87 \\
\mathrm{P}<0.01 * \mathrm{c}\end{array}$ \\
\hline Urea (mg/dl) & $27.14 \pm 3.23$ & $\begin{array}{l}71.99 \pm 3.41 \\
\mathrm{P}<0.0001 * \mathrm{a}\end{array}$ & $\begin{array}{c}76.12 \pm 4.06 \\
P>0.05 b\end{array}$ & $\begin{array}{l}44.21 \pm 4.15 \\
\mathrm{P}<0.002 * \mathrm{c}\end{array}$ \\
\hline MDA $(\mu \mathrm{mol} / \mathrm{L})$ & $19.23 \pm 1.37$ & $\begin{array}{l}45.41 \pm 3.85 \\
\mathrm{P}<0.0001 * \mathrm{a}\end{array}$ & $\begin{array}{c}46.67 \pm 4.91 \\
P>0.05 b\end{array}$ & $\begin{array}{l}30.47 \pm 1.25 \\
\mathrm{P}<0.0001 * \mathrm{c}\end{array}$ \\
\hline TNF- $\alpha$ (Pg / ml) & $28.29 \pm 2.84$ & $\begin{array}{c}91.6 \pm 3.29 \\
\mathrm{P}<0.0001 * \mathrm{a}\end{array}$ & $\begin{array}{c}85.69 \pm 6.32 \\
P>0.05 b\end{array}$ & $\begin{array}{l}47.24 \pm 5.97 \\
\mathrm{P}<0.0001 * \mathrm{c}\end{array}$ \\
\hline
\end{tabular}

a: comparing groups I and II b: comparing groups II and III c: comparing groups IV and II

Histopathological examination:

In group I, kidney tissue showed normal histological structure of the glomeruli and tubules in the cortical portion (Fig.4A). Group II and group III showed distortion of renal architecture in 
the form of hyperemia with swelling in the lining epithelium of the glomeruli and partial loss of brush border of proximal convoluted tubules as well as necrotic lesions in epithelial lining of urinary tubules (Fig. B and C). Group IV showed restoration of renal architecture and normal dilation of renal lumens lined by regenerative cells (Fig. 4D).
Immunohistochemistry: In group I slight expression of BAX protein were detected by appearance of yellow brown color (Fig. 4E), Groups II and III showed marked expression of BAX protein (Fig. 4 $F$ and G), while group IV showed significant decrease in expression of BAX compared to group II (Fig. 4H).
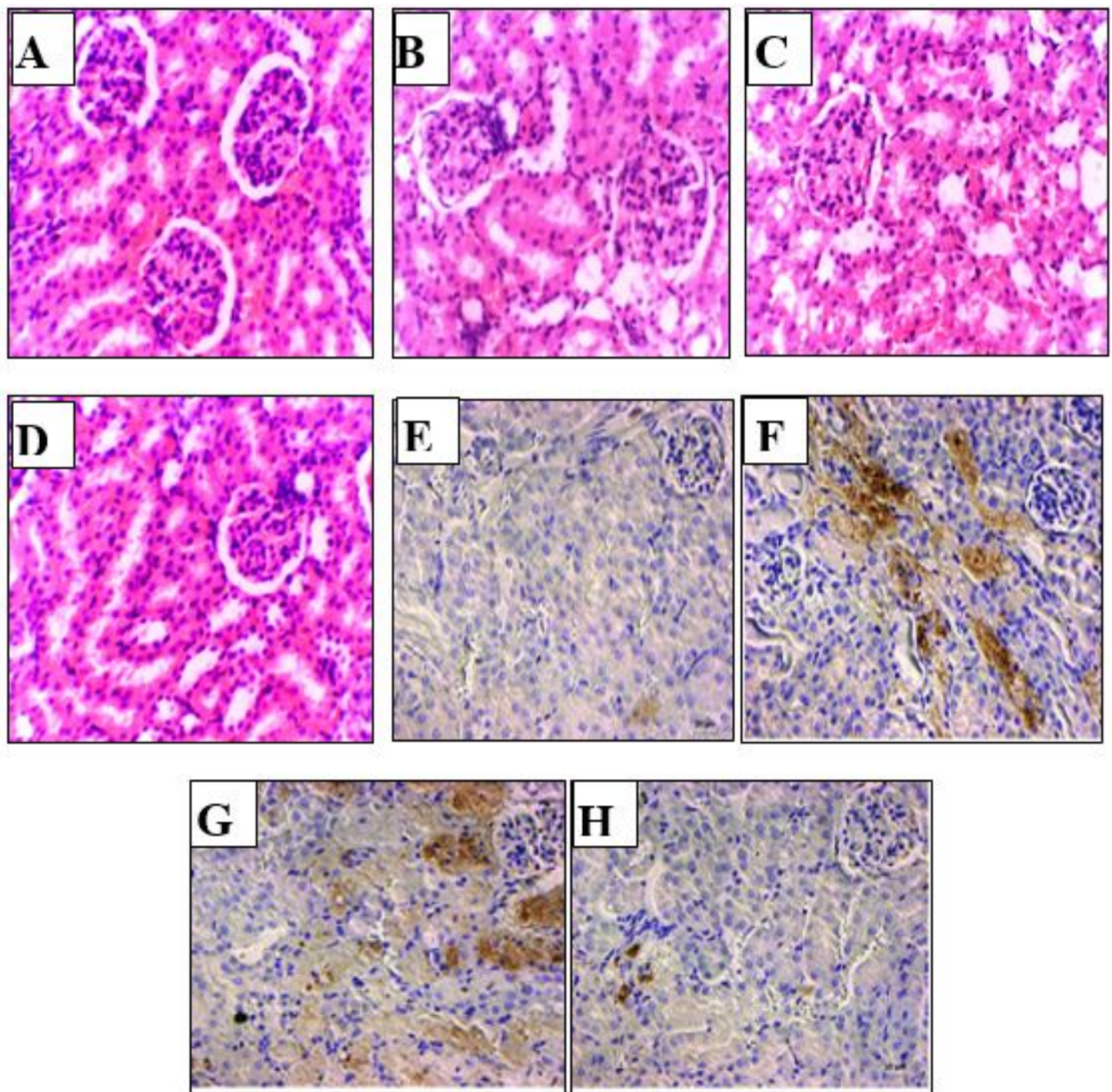

Figure (4): Group I showed normal architecture of glomeruli and kidney tubules (4A). There were congestion and hypremia of glomeruli and loss of brush border of kidney tubules in groups II and III (4B and C). There were restoration of renal architecture and normal dilation of kidney tubules in group IV (H\& E, X400) (4D). Slight expression of BAX in group I (4E), Strong expression of BAX in groups II and III indexed by appearance of dark brown color ( $4 \mathrm{~F}$ and $\mathrm{G}$ ), and restoration of the normal expression of BAX in group IV $(4 \mathrm{H})$. 


\section{DISCUSSION}

The renal failure group which was subjected to oral administration of acetaminophen showed significant increase in serum creatinine and urea compared to control group, these results agreed with (Zaher et al., 2008) and (Gopi et al., 2010). In the current work, there were significant increase in serum MDA in acetaminophen- treated group compared to control group, which indicated occurrence of lipid peroxidation and oxidative stress. This result agreed with (Karaali et al., 2018) and (Singh et al., 2011). Significant increase in serum TNF- $\alpha$ in acetaminophen-treated group compared to control group indicating that acetaminophen triggered inflammatory process and release of proinflammatory cytokines which agreed with (Yan et al., 2016). Significant decreases occurred in BCL2 gene expression, in addition to increased expression of BAX by immunohistochemistry in acetaminophen - treated group. This agreed with the results of (Banu et al., 2011) and Al(Rasheed et al., 2017). There were increased expression of BAX protein, and decreased BCL2 gene expression in the kidney tissue in acetaminophen - treated group compared to control group, which agreed with (Al-Rasheed et al., 2017) and (Fadda et al., 2018).

In the current work, there were significant decrease in serum creatinine, urea, MDA and TNF- $\alpha$, while there was significant increase in BCL2 gene expression in MSCs derived MVs - treated group in comparison with acetaminophen - treated group. In addition, there was a significant decrease in BAX protein expression in MSCs derived MVs - treated group. These results agreed with (Bruno et al., 2009), (Tan et al., 2014), (Sun et al., 2017), (Ebrahim et al., 2018) and (Shi et al., 2018).

A reactive metabolite of acetaminophen that caused oxidative damage to tissues might be the reason for its reno-toxic effects (Gopi et al., 2010). Acetaminophen overdose is often linked to many metabolic disorders including serum electrolyte, urea and creatinine derangements. Increased concentration of serum urea and creatinine is considered for investigating drug induced nephrotoxicity in animals and man (Pradhan et al., 2013).

Tumor necrosis factor (TNF or TNF- $\alpha$ ) is a major pro-inflammatory cytokine involved in early inflammatory events. It trigger a series of various inflammatory molecules (Parameswaran and Patial, 2010).

Bcl-2, a gene located at chromosome $18 \mathrm{q} 21$, encodes a $26-\mathrm{kD}$ protein that blocks programmed cell death without affecting cellular proliferation. The BAX protein is a member of the bcl- 2 family that promotes apoptosis, the ratio of bax to bcl-2 determines the susceptibility of a cell to apoptosis (Bergmann and Steller, 2010 and Al-Rasheed et al., 2017). The BCL-2 and BAX perform anti-apoptotic and pro-apoptotic roles, respectively (Banu et al., 2011). The role of BAX in the regulation of apoptosis initiated by deprivation of survival factors or by lethal cytokines, such as tumor necrosis factor (TNF), has been previously explored in renal tubular epithelium, in addition to decrease in the expression of BCL2 mRNA and protein (Tzifi et al., 2012). Paracetamol decreased BCL2 protein 
without significantly changing its mRNA levels (Lorz et al., 2005).

As discussed above, several studies in animal models of CKD suggest that MSCderived EVs can effectively preserve renal structure and function. So far, however, only one clinical trial has tested the renoprotective effects of MSC-derived EVs on the progression of CKD (Nargesi et al., 2017). In this phase II/III pilot study, 40 patients with estimated GFR (eGFR) between 15 and $60 \mathrm{ml} / \mathrm{min}$ were randomized to receive either placebo or EVs derived from allogenic cord blood MSCs. Patients were treated with two doses of EVs and followed for 12 months. EV therapy improved eGFR, serum creatinine, and BUN levels, as well as urinary albumin/creatinine ratio. Plasma levels of TNF- $\alpha$ decreased, whereas levels of IL-10 increased in EV-treated patients. Renal biopsy findings 3 months after intervention revealed that EV-treated kidneys showed upregulated expression of cell regeneration and differentiation markers (Nassar et al., 2016). (Bruno et al., 2012) reported that multiple injections of MVs further decreased mortality and at day 21 surviving mice showed normal histology and renal function. The mechanism of protection was mainly ascribed to an anti-apoptotic effect of MVs. In vitro studies demonstrated that MVs up-regulated in cisplatin-treated human tubular epithelial cells antiapoptotic genes, such as Bcl2 and BIRC8 and down-regulated genes that have a central role in the execution-phase of cell apoptosis such as BAX, Casp1, Casp8 and LTA. The accumulation of EVs in tissue could be promoted by the increased permeability of damaged tissues, the internalisation of $\mathrm{EVs}$ depends on the presence of cell receptors $(\mathrm{CRCX} 4)$ and adhesion molecules (CD44 and CD29); the latter are found in both $\mathrm{EV}$ and MSC membranes (Roviraa et al., 2017).

\section{CONCLUSION}

MSCs-derived EVs have
significant regenerative effect in
acetaminophen-induced nephrotoxicity by
antioxidants, anti-inflammatory and anti-
apoptotic mechanisms.

\section{REFERENCES}

1. Al-Rasheed, N., Faddah, L.M., Hasan, I.H., Ali, H.M., Al-Rasheed, N., El Oraby, N.F. and Mohamed, M.H. (2017): Amelioration of panadol-induced nephrotoxicity via downregulation of $\mathrm{Bax} / \mathrm{Bcl} 2$ ratio with some antioxidants. Pharmacol. Rep., 69:1088-1093.

2. Bancroft, J.D., Stevens, A. and Turner, D.R. (1996): Theory and practice of histological techniques, 4th edn, Pbl: Churchil, Livingston, San Francisco, Tokyo pages: 915-922.

3. Banu, S.K., Stanley, J.A., Lee, J., Stephen, S.D., Arosh, J.A., Hoyer, P.B. and Burghardt, R.C. (2011): Hexavalent chromium-induced apoptosis of granulosa cells involves selective sub-cellular translocation of Bcl-2 members, ERK1/2 and p53. Toxicol. Applied Pharmacol., 251: 253-266.

4. Bergmann, A. and Steller, H. (2010): Apoptosis, Stem Cells, and Tissue Regeneration. Sci. Signal., 3: 1-8.

5. Bruno, S. and Camussi, G. (2014): Exploring mesenchymal stem cell-derived extracellular vesicles in acute kidney injury. Methods Mol. Biol., 1213:139-145.

6. Bruno, S., Chiabotto, G. and Camussi, G. (2014): Concise review: different mesenchymal stromal/stem cell populations reside in the adult kidney. Stem Cells Transl. Med., 3:1451-1455.

7. Bruno, S., Grange, C., Collino, F., Deregibus, M.C., Cantaluppi, V., Biancone, L.C., and Camussi, G. (2012): Microvesicles Derived from Mesenchymal Stem Cells Enhance Survival in a Lethal Model of Acute Kidney Injury. PLoS One, 7: e33115. 
8. Bruno, S., Grange, C., Deregibus, C., Calogero, R.A., Saviozzi, S., Collino, F., Morando, L., Busca, A., Falda, M., Bussolati, B., Tetta, C. and Camussi, G. (2009): Mesenchymal Stem Cell-Derived Microvesicles Protect Against Acute Tubular Injury. JASN, 20: 1053-1067.

9. Campion, C.G., Sanchez-Ferras, O. and Batchu, S.N. (2017): Potential Role of Serum and Urinary Biomarkers in Diagnosis and Prognosis of Diabetic Nephropathy. Can. J. Kidney Health Dis., 4:2054-2071.

10. Cantaluppi, V., Biancone, L. and Quercia, A. (2013): Rationale of mesenchymal stem cell therapy in kidney injury. Am. J. Kidney Dis., 61:300-309.

11. Charbord, P. (2010): Bone marrow mesenchymal stem cells: historical overview and concepts. Hum. Gene Ther., 21:1045-1056.

12. Ebrahim, N., Ahmed, I.A., Hussien, N.I., Dessouky, A.A., Farid, A.S., Elshazly, A.M., Mostafa, O., El Gazzar, W.B., Sorour, SM., Seleem, Y., Hussein, A.M. and Sabry, D. (2018): Mesenchymal Stem Cell-Derived Exosomes Ameliorated Diabetic Nephropathy by Autophagy Induction through the mTOR Signaling Pathway. Cells, 7: 226-251.

13. Fadda, L.M., AL-Rasheed, N., Hasan, I.M. and Ali, H.M. (2018): Bax and CD68 Expression in Response to Liver Injury Induced by Acetaminophen: The Hepatoprotective Role of Thymoquinone and Curcumin. Pakistan journal of Zoology, 49: 85-93.

14. Folin, O. and Wu, H. (1976): Jaffe method for creatinine estimation. J.Biol. Chem., 38:8189.

15. Gopi, K.S., Reddy, A.G., Jyothi, K. and Kumar, B.A. (2010): Acetaminophen-induced Hepato- and Nephrotoxicity and Amelioration by Silymarin and Terminalia chebula in Rats. Toxicol. Int., 17: 64-66.

16. Hsu, R.K. and Powe, N.R. (2017): Recent trends in the prevalence of chronic kidney disease: not the same old song. Curr. Opin. Nephrol. Hypertens. 26:187-196.

17. Karaali, H.F., Fahmi, R.R. and Borjac, J.M. (2018): Effect of Ocimum basilicum leaves extract on acetaminophen-induced nephrotoxicity in BALB/c mice. J. Complement Integr. Med., 95:351-358.

18. Krajewski, S., Bodrug, S., Krajewska, M., Shabaik, A., Gascoyne, R., Berean, K. and Reed, J.C. (1995): Immunohistochemical analysis of Mci-1 protein in human tissues: differential regulation of $\mathrm{Mci}-1$ and $\mathrm{Bcl}-2$ protein production suggests unique role for McI-1 in control of programmed cell death in vivo. Am. Pathol., 146:1309-1319.

19. Kwon, A., Kim, Y., Kim, M., Kim, J., Choi1, H., Jekar, D.W., Lee, S., Kim, J.M., Shin, J. and Park, I. (2016): Tissue-specific Differentiation Potency of Mesenchymal Stromal Cells from Perinatal Tissues Scientific Reports, 6:235-244.

20. Lorz, C., Justo, P., Belan, N.A., Egido, S.J. and Ortiz, A. (2005): Role of Bcl-xL in paracetamol-induced tubular epithelial cell death. Kidney International, 67: 592-601.

21. Lozano, R., Naghavi, M., Foreman, K., Lim, S., Shibuya, K., Aboyans, V., Abraham, J., Adair, T., Aggarwal, R., Ahn, S., Alvarado, M., Anderson, H., Anderson, L., Andrews, K. and Atkinson, C. (2012): Global and regional mortality from 235 causes of death for 20 age groups in 1990 and 2010: a systematic analysis for the Global Burden of Disease Study 2010. Lancet, 380: 2095-2128.

22. Nargesi, A.A., Lerman, L.O. and Eirin, A. (2017): Mesenchymal stem cell-derived extracellular vesicles for kidney repair: current status and looming challenges. Stem Cell Res. Ther., 8: 273-282.

23. Nassar, W., El-Ansary, M., Sabry, D., Mostafa, M.A., Fayad, T., Kotb, E., Temraz, M., Saad, A.N., Essa, W. and Adel, H. (2016): Umbilical cord mesenchymal stem cells derived extracellular vesicles can safely ameliorate the progression of chronic kidney diseases. Biomater. Res., 20: 21-31.

24. Onuigbo, M.A. (2013): Syndrome of rapidonset end-stage renal disease in two consecutive renal transplant recipients. Indian J. Nephrol., 23: 222-225.

25. Parameswaran, N. and Patial, S. (2010): Tumor Necrosis Factor- $\alpha$ Signaling in 
Macrophages. Crit. Rev. Eukaryot. Gene Expr., 20: $87-103$.

26. Patton, C.J. and Crouch, S.R. (1977): Spectrophotometric and kinetics investigation of the Berthelot reaction for the determination of ammonia. Anal. Chem., 49: 646-469.

27. Petrovas, C., Daskas, S.M. and Lianidou, E.S. (1999): Determination of tumor necrosis factor-alpha (TNF-alpha) in serum by a highly sensitive enzyme amplified lanthanide luminescence immunoassay. Clin. Biochem. 32: 241-247.

28. Pfaffl, M.W. (2001): A new mathematical model for relative quantification in real-time RT-PCR. Nucleic Acids Res., 29: 45-53.

29. Placer, Z.A., Cushman, L.L. and Johnson, B.C. (1966): Estimation of product of lipid peroxidation (malonyl dialdehyde) in biochemical systems. Analytical Biochemistry, 16: $359-364$

30. Pradhan, S., Mandal, S., Roy, S., Mandal, A., Das, K. and Nandi, D.K. (2013): Attenuation of uremia by orally feeding alphalipoic acid on acetaminophen induced uremic rats. Saudi Pharm. J., 21: 187-192.

31. Roushandeh, A.M., Bahadori, M. and Roudkenar, M.H. (2017): Mesenchymal Stem Cell-based Therapy as a New Horizon for Kidney Injuries. Arch. Med. Res., 48:133-146.

32. Roviraa, J., Diekmanna, F., Campistola, J.M. and Ram?rez-Bajoa, M.J. (2017): Therapeutic application of extracellular vesicles in acute and chronic renal injury. Nefrologia, 37: $126-137$.

33. Shi, B., Wang, Y., Zhao, R., Long, X., Deng, W. and Wang, Z. (2018): Bone marrow mesenchymal stem cell-derived exosomal miR21 protects C-kit+ cardiac stem cells from oxidative injury through the PTEN/PI3K/Akt axis. PLoS One, 13:e0191616.

34. Singh, S., Shanker, K., Kumar, M., Chandra, K. and Singh, R. (2011): Ameliorative Potential of Quercetin Against Paracetamol-induced Oxidative Stress in Mice Blood. Toxicol. Int., 18: 140-145.

35. Sun, L., Li, D., Song, K., Wei, J., Yao, S., Li, Z., Su, X., Ju, X., Deng, L., Kong, B. and Li,
L. (2017): Exosomes derived from human umbilical cord mesenchymal stem cells protect against cisplatin-induced ovarian granulosa cell stress and apoptosis in vitro. Sci Rep., 7: 25522564.

36. Tan, C.Y., Lai, R.C., Wong, R., Dan, Y.Y., Lim, S.K. and Ho, H.K. (2014): Mesenchymal stem cell-derived exosomes promote hepatic regeneration in drug-induced liver injury models. Stem Cell Res. Ther., 5: 76-81.

37. Tetta, C., Weiss, S. and Grange, C. (2016): Adult Stem Cells and Extracellular Vesicles in Acute and Chronic Kidney Injury. Current Regenerative Medicine, 6: 2-15.

38. Théry, C., Amigorena, S., Raposo, G. and Clayton, A. (2006): Isolation and characterization of exosomes from cell culture supernatants and biological fluids. Current Protocols in Cell Biology. Pbl: John Wiley \& Sons, Inc; Chapter 3: Unit 3.22.10.1002/0471143030.cb0322s30.

39. Tzifi, F., Economopoulou, C., Gourgiotis, D., Ardavanis, A., Papageorgiou, S. and Scorilas, A. (2012): The Role of BCL2 Family of Apoptosis Regulator Proteins in Acute and Chronic Leukemias. Adv. Hematol., 69: 524538.

40. Yan, T., Wang, H., Zhao, M., Yagai, T., Chai, Y., Krausz, K.W., Xie, C.,Cheng, X., Zhang, J., Che, Y., Li, F., Wu, Y., Brocker, C.N., Gonzalez, F.J., Wang, G. and Hao, H. (2016): Glycyrrhizin Protects against Acetaminophen-Induced Acute Liver Injury via Alleviating Tumor Necrosis Factor $\alpha-$ Mediated Apoptosis. Drug Metab. Dispos., 44: 720-731.

41. Zaher, A., Hady, H., Mahmoud, M. and Farrag, M. (2008): The potential protective role of alpha-lipoic acid against acetaminophen-induced hepatic and renal damage. Toxicol. 243:261-70. 


\section{تأثير الحويصلات المفصولة من الخلايا الجذعية علي الإصابة

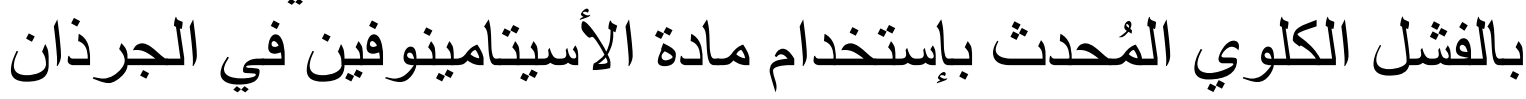 البيضاء البالغة البئة}

سعد محمد محمد ـ أسامه محمد محمد عبدالحي - إبراهيم حسن محمد*ـ أحمد منصور يوسف قنديل***

أقسام الفسيولوجيا الطبية والكيمياء الحيوية الطبيةث*و الباثولوجيا **** ـ كلية الطب ـ جامعة الأزهر

خلفيـة البحثث : هنـالك حاجـة ماسـة لإستخدام علاجـات متفردة لتو اجـه الإرتفـاع في معدل حدوث الفشـل

الكلوي الحاد و المزمن. والحويصلات المنفصلة من الخلايا الجذعية لها دور في بنـاء الأنسجة التالفة بالإضـافة لإنة إلي منع حدوث التلف.

الهـدف مـن البحث: دراسـة دور العـلاج بالحويصـلات المنفصـلة مـن الخلايـا الجذعيـة في حـالات الفثـل الكلوي المحدث تجريبيا في ذكور الجرذان البيضاء.

مواد و طرق البحث: استخدم في هذا البحث أربعة وعشرون فأراً أبيضاً بالغاً من فصبلة محلية مقسمة إلي

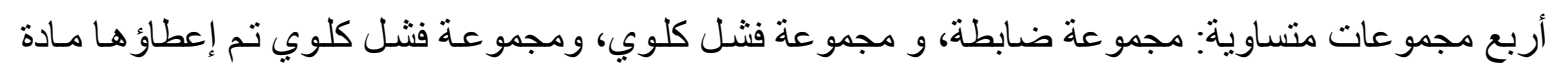
وسط زر اعة الخلايا، ومجمو عة فثل كلوي تم إعطاؤ ها الحويصلات المفصولة من الخلايـا الجذعية. و قد تد تم

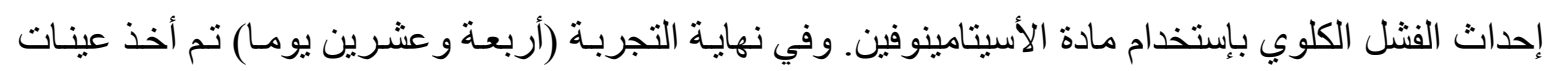

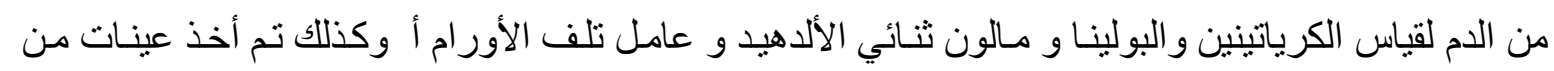

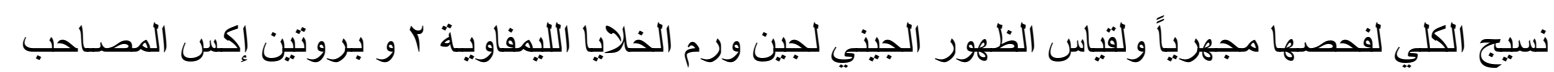

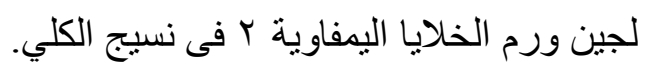

النتائج: أحدث الأسيتامينوفين إرتفاعاً في الكرياتنينين والبولينا ومالون ثنائي الألدهيد و عامل تلف الخلايـا أ

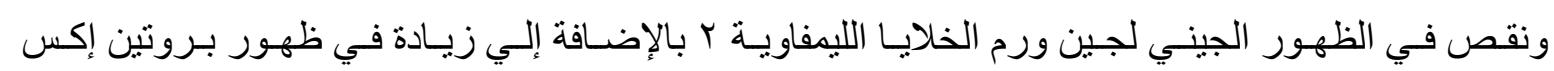

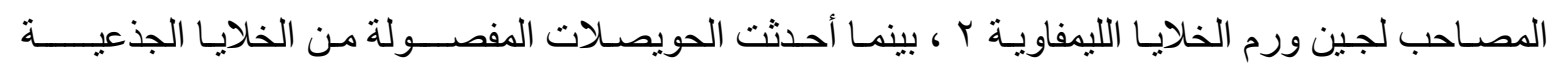

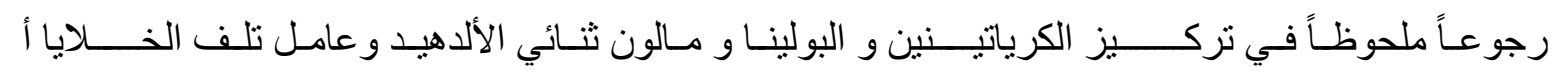
و الظهور لبروتين إكس المصاحب لجين ورم الخلايا الليمفاوية ب بالإضافة إلي زيادة في الظهور الجيني لجين الجين

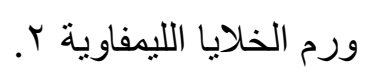

الاستتتاج: للعلاج بالحويصلات المفصولة من الخلايا دور كبير في إلتئام نسيج الكلي في حالات الإصـابة بالفتل الكلوي المحدث تجريباً عن طريق تقليص عملية الأكسة و الإلتهابات و موت الخلايا المبرمج. 